\title{
РОЛЬ ІНТЕРАКТИВНИХ МЕТОДІВ В ОПТИМІЗАЦІЇ ПРОЦЕСУ ВИКЛАДАННЯ ДИСЦИПЛІНИ «ЕТИКА ТА ДЕОНТОЛОГІЯ У ФАРМАЦІЇ»
}

\author{
I. P. Stechyshyn, A. I. Denys \\ I. Horbachevsky Ternopil National Medical University \\ THE ROLE OF INTERACTIVE METHODS IN OPTIMIZATION OF \\ TEACHING PROCESS OF THE ETHICS AND DEONTOLOGY IN \\ PHARMACY
}

\begin{abstract}
Анотація. У статті наведено застосування методу «Інтерактивна дискусія» під час проведення семінарського обговорення з дисципліни «Етика та деонтологія у фармації» зі студентами фармацевтичного факультету першого року навчання. Зазначено, що використаний метод дав можливість всебічно розглянути поставлені проблеми та однаковою мірою залучити до їхнього обговорення всіх учасників, незалежно від їх рівня підготовки, здібностей, характеру тощо. Це є важливою перевагою, оскільки при традиційному підході до проведення заняття, враховуючи складність матеріалу, наповненість групи та тривалість заняття (1,5 год), досить складно якісно опитати та оцінити усіх студентів. Разом з тим, засвоєння усіма студентами навчального матеріалу у повному обсязі є важливим елементом при підготовці кваліфікованих фармацевтичних фахівців.

Сьогодні конкурентне середовище вимагає від провізорів знань та успішного застосування стандартів обслуговування, володіння комерційними технологіями, психологією продаж, навичок умілої презентації, вміння володіти конфліктною ситуацією та ін. Адже досить часто споживачі розлючені через відсутність потрібного препарату чи надмірно високу його ціну, створюючи конфліктну ситуацію. Успішне вирішення таких проблем можливе за умови етичної поведінки та культурного спілкування фармацевтичного фахівця у конкретній ситуації.

У статті описано обговорення ситуаційних задач як елементу методу «Інтерактивна дискусія». Для їх опрацювання учасники були поділені на групи і виконували послідовні кроки: «Робота в парах», «Рольова гра», «Пошук рішення» і «Написання есе». У відповідях студенти виявляли творчий підхід до вирішення ситуаційних задач, розглядаючи їх з різного ракурсу (пацієнта, провізора, керівника аптеки, лікаря). На завершення семінарського заняття проводилось опитування студентів («Плюси, мінуси, запитання») щодо доцільності використання даного методу у викладанні предмета «Етика та деонтологія у фармації». Студенти оцінили продуктивність роботи в команді позитивно.
\end{abstract}

Ключові слова: етика; деонтологія; інтерактивні методи навчання; фармацевтичний фахівець.

Abstract. The article considers the use of the Interactive Discussion method during seminar discussions in the Ethics and Deontology in Pharmacy discipline with first-year students of the Pharmacy Faculty. It is stated that this method provides an opportunity to thoroughly address the issues raised and equally involve all the participants into discussion, regardless of the level of their training, abilities, character etc. This is an important advantage because it is rather difficult to access all students when applying a traditional approach in a class due to the complexity of study material, the number of people in a group and the duration of a class (1.5 hours). Meanwhile, comprehensive understanding of the study material by all students is a vital part of training qualified pharmaceutical specialists.

Nowadays, in the competitive environment, pharmacists are required to know and successfully apply service standards, commercial technology, sales psychology, profound presentation skills, ability to handle conflicts etc. After all, quite often consumers get angry due to the lack of required medicine or its excessively high price and provoke the pharmacist behind the counter to conflict. Such problems can be successfully resolved provided the pharmaceutical specialist keeps their behavior ethical and communicates politely in a particular situation.

The article describes discussing situational tasks as an element of the Interactive Discussion method. The participants were divided into groups and did the following tasks in a row: "Working in pairs", "Role playing”, "Finding a solution” and "Writing an essay". When answering, the students displayed creativity solving situational problems, considering them from different angles (of a patient, pharmacist, pharmacy manager, doctor). At the end of the seminar, students were interviewed about the feasibility of using this method in teaching the Ethics and Deontology in Pharmacy subject (Advantages, Disadvantages, Questions). The students provided positive feedback on the productivity of the teamwork.

Key words: ethic; deontology; interactive methods of studying; pharmaceutical specialist.

(C) І. П. Стечишин, А. І. Денис 
Вступ. Динамічний розвиток вітчизняної фармацевтичної галузі базується на таких шести складових, як: фармацевтична освіта, наука, фармацевтична промисловість, державна система контролю якості лікарських засобів, аптечна мережа й інформаційне поле фармації. Тільки за умови скоординованої ефективної діяльності всіх цих складових можливе досягнення основної мети фармації - забезпечення здоров'я нації [4]. Досягнення цієї цілі неможливе без визначення чітких норм етичної поведінки, усвідомлення ролі етики та деонтології у формуванні особистості майбутнього фармацевтичного фахівця [2].

Етика та деонтологія повинна стати обов'язковим атрибутом діяльності майбутнього спеціаліста, тому що володіння основами етики, її практичним використанням у діловому спілкуванні з клієнтами, партнерами по бізнесу, посередниками, населенням загалом допомагає суттєво підвищити професійний рівень у конкурентному середовищі [1].

Для досягнення таких цілей організація навчального процесу у вищому закладі освіти має бути спрямована на роботу студентів з формування професійних якостей, необхідних майбутньому спеціалісту. Розвиток значущих професійних якостей можливий завдяки інтегруванню теоретичних знань у конкретні практичні уміння за допомогою певних методів навчання. Цим вимогам оптимально відповідають інтерактивні методи навчання [5].

Мета дослідження - дослідити вплив інтерактивних методів навчання на освоєння етичних аспектів професійних комунікацій фармацевтичних фахівців та ефективність їх застосування у практичних ситуаціях.

Методи дослідження. У процесі дослідження застосовували метод групової дискусії як активної форми обміну інформацією між студентами та викладачем. За допомогою письмового опитування проводили збір інформації щодо якості проведеного семінару «Плюси, мінуси, запитання». Кінцеву інформацію унаочнювали із використанням графічного методу для проведення подальшого аналізу.

Результати дослідження. У дослідженні взяли участь вітчизняні та іноземні студенти першого курсу фармацевтичного факультету $(\mathrm{n}=76)$. Основою вивчення цієї теми стали соціально сформовані норми етикету, виховання, що базуються на правилах та національних традиціях, а також елементарні навички спілкування з людьми. Для розкриття теми заняття студенти ознайомлювалися з теоретичним матеріалом у формі лекції та матеріалів підготовки до заняття.

Вхідний контроль проводили за методикою «Експрес-опитування» (завдання на зразок «продовж речення») з метою моніторингу готовності студентів до семінарського обговорення.

У ході проведення заняття використовували метод «Інтерактивна дискусія» [3] для того, щоб всебічно розглянути проблему та залучити до ї̈ обговорення всіх учасників, незалежно від їх рівня підготовки, здібностей, характеру тощо.

Дискусія розпочиналася з вибору проблеми для обговорення. Для активізації навчально-пізнавальної діяльності студентів використовувалися ситуаційні задачі (для кожної групи формувалися різні варіанти). Наприклад:

1. В аптеку звернувся відвідувач з проханням відпустити дитині віком 3 роки будь-який лікарський засіб для лікування ангіни. Які дії провізора?

2. В аптеку звернувся відвідувач з проханням відпустити дитині віком 3 роки будь-який лікарський засіб для лікування проносу, що триває три дні. Паралельно у дитини підвищена температура та блювання. Які дії провізора?

3. В аптеку звернувся пацієнт із проханням виміряти йому артеріальний тиск. Провізор відповів, що на даний момент не має на це часу, хоча в аптеці черги не було і перед входом в аптеку $\epsilon$ оголошення про те, що аптека надає послуги з вимірювання артеріального тиску.

Дискусія проводилась на базі навчальної аптеки кафедри під керівництвом викладача, який допомагав студентам розібратись у клінічних ситуаціях (предмети цього спрямування вони вивчатимуть на старших курсах), направляючи їх відповідь в етичну площину.

Організація робочого процесу:

Крок 1. («Робота в парах»). Об’єднували учасників по двоє в пари і давали такі завдання:

1. Обговоріть ситуаційне завдання в парах 2-3 хв.

2. Працюючи разом, запишіть можливі варіанти вирішення запропонованого завдання (це допомагає подумати про питання з різних позицій).

Крок 2. («Рольова гра»). Переформовували учасників у 4 групи. Попередньо приготували 4 паперові жеребки з чотирма ролями, написаними на них. Наприклад, для обраної теми були запропоновані такі ролі: 1) колега по роботі; 2) пересічний пацієнт-відвідувач; 3) лікар; 4) провізор. По одному представнику від кожної групи запрошувалось витягнути жереб - вибрати роль. Викладач надавав 
деякі підказки, натяки щодо характеристики обраних ролей, а також наголошував, що вони можуть бути як позитивними, так і негативними всередині однієї групи. Завдання тривало 5-10 хв:

1. Уявіть себе в обраній ролі.

2. Підготуйте коротку презентацію своєї ролі. Як ваш персонаж ставиться до ситуаційної задачі, що обговорюється?

3. Виконайте вашу роль. Для цього оберіть у групі представника або кількох, які презентують роль перед аудиторією.

4. Вислухайте презентації всіх груп.

5. Чия рольова презентація була найбільш переконливою?

6. Хто змінив своє ставлення до проблеми, що обговорюється? Чому?

Крок 3. («Пошук рішення»). Усіх учасників розділили в групи, де вони відстоювали свої позиції: «Згоден», «Не згоден», «Не можу визначитися». Утвореним групам були запропоновані такі завдання:

1. Залишаючись у ваших ролях (у кожній групі тепер представлені всі ролі), спробуйте організувати загальне обговорення з метою знайти вихід із суперечливої проблеми, що обговорювалася, щоб захистити людські цінності, дотримати інтересів і досягти суспільної згоди - консенсусу.

2. Представте ваше спільне рішення перед групою.

3. Обговоріть, чиї пропозиції були цікавими, раціональними і перспективними?

Після цього завдання студенти давали відповіді на запитання викладача:

1. Для чого ми проводили таке обговорення?

2. Що нового ви дізналися? Які навички ви набули під час дискусії і як ці навички можна використати у повсякденному житті?

3. Які цінності та інтереси зіткнулися у цій проблемі?

4. Що ви відчували під час дискусії?

5. Чи відчуваєте вдоволення чи невдоволення результатами дискусії? Чому?

6. Чи може бути обговорювана проблема насправді вирішена? Чому так/ні?

Крок 4. («Написання есе»). Студентам запропонували написати коротке есе та пояснити, чому кожен із них підтримував ту чи іншу позицію; проаналізувати ситуацію, яка розглядалась; прокоментувати свій вибір. (Такий крок допомагає побачити загальну картину - результат обговорення, психологічний клімат у групі й успішність усієї дискусії. Есе буде цікавим, якщо в ньому будуть наявні непередбачувані (парадоксальні) висновки, несподівані повороти.)

У відповідях студенти виявляли творчий підхід до вирішення ситуаційних задач, розглядаючи їх з різного ракурсу (пацієнта, провізора, керівника аптеки, лікаря). У зв'язку з недостатністю професійних знань та вмінь студенти пропонували власні варіанти вирішення ситуаційних задач, які не завжди були доречні та правильні. У прийнятті рішень вони більше керувалися емпатійним розумінням, ніж раціональним мисленням, що, в принципі, не применшувало їхньої готовності надати допомогу.

На завершення семінарського заняття проводилось опитування «Плюси, мінуси, запитання». Студенти отримали по три аркуші паперу, на яких висловлювали свої думки з приводу семінару, вказуючи, які були позитивні моменти («+»), які негативні («-») та що викликало запитання або сумніви. Викладач наголошував на тому, що підписувати свої коментарі необов'язково (у разі анонімної оцінки студенти більш відверті). Після заняття викладач читав та аналізував результати зворотного зв'язку та наступне заняття розпочинав 3 власного враження на оцінки студентів з приводу попереднього заняття.

В цілому, студенти оцінювали свою продуктивність роботи в команді позитивно (рис. 1). Більшість студентів також оцінювала інших членів команди позитивно, але, як і очікувалося, деякі члени групи домінували в дискусіях. Загалом студенти зазначали, що використання на занятті інтерактивних методів дозволило їм самостійно відповідати, бути активнішими в отриманні знань, захищати свою точку зору в дискусії та висловлювати свої погляди на етичну дилему.

\section{Опитування «Плюси, мінуси, запитання»}

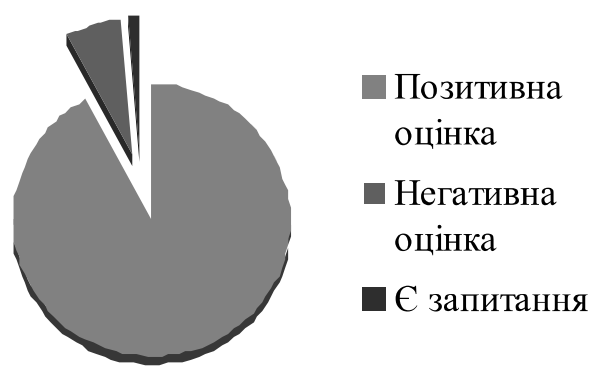

Рис. 1. Результати опитування студентів.

Висновки та перспективи подальших досліджень. Навчання на основі команди може бути оптимальним підходом до викладання дисципліни «Етика та деонтологія у фармації», оскільки перед- 
бачає активну участь кожного в групі, дозволяє студентам бачити різні сторони ситуації, формувати правильне сприйняття та вирішення проблем.

Володіння психологічними навичками визначення типу людей, швидкістю та якістю прийняття рішень, вміннями обслуговування в аптеці та контролю за ним свідчитимуть про набуття студентами досвіду, який знадобиться майбутнім провізорам в ідентифікації себе в роботі за фахом, відданому

\section{Список літератури}

1. Викладання етики та деонтології у фармації / А. С. Гоцуля, Н. А. Постол, А. Г. Каплаушенко [та ін.] // Актуальні проблеми сучасної медицини. - 2010. - Т. 10, № 4. - С. 175-177.

2. Етика та деонтологія у фармації : метод. рек. до семінарських занять студентів освітньої програми «Фармація» (2,5; 4,5 р. н.) заочної форми навч. та «Технологія парфумерно-косметичних засобів» денної та заочної форм навч. / [А. А. Котвіцька, Н. В. Чмихало, І. І. Свєточева та ін.] ; за заг. ред. А. А. Котвіцької. - Х. : НФаУ, 2017. -54 c.

\section{References}

1. Hotsulia, A.S., Postol, N.A., Kaplaushenko, A.H., Parchenko, V.V., \& Shchvets, V.M. (2010). Vykladannia etyky ta deontolohii u farmatsii [Teaching ethics and deontology in pharmacy]. Aktualni problemy suchasnoi medytsyny - Urgent Problems of Modern Medicine, (4), 175-177 [in Ukrainian].

2. Kotvitska, A.A., Chmykhalo, N.V., \& Svietocheva, I.I. (2017). Etyka ta deontolohiia u farmatsii [Ethics and deontology in pharmacy]. Kotvitska, A.A. (Eds.), Metod. rek. do seminarskykh zaniat studentiv osvitnoi prohramy “Farmatsiia” (2,5; 4,5 r.n.) zaochnoi formy navch. ta "Tekhnolohiia parfumerno-kosmetychnykh zasobiv" dennoi ta zaochnoi form navch - Methodological Seminar Recommendations for Distant Pharmacy Students (2,5; 4,5 years) and Full-time Perfume and Cosmetics Technology Students. Kharkiv: NFaU [in Ukrainian]. служінню людям та відповідності критеріям ВООЗ «фармацевта семи зірок» - найвищим вимогам щодо рівня фахівців формації нового часу.

Метод інтерактивної дискусії є перспективним для дослідження його використання при вивченні ряду дисциплін, що викладаються на кафедрі управління та економіки фармації з технологією ліків.

3. Методична скарбничка [Електронний ресурс]. - Peжим доступу : https://www.novadoba.org.ua/sites/default/ files/files/common_history_book/methodical.pdf.

4. Фармацевт «семи зірок» - основа аптечного закладу європейського зразка [Електронний ресурс] // Сайт «Ліки в Україні». - 2013. - Режим доступу : http://xn-h1adc2i.xn--j1amh/news/03518.html.

5. Ящишина Ю. М. Використання інтерактивних методів навчання при викладанні дисциплін з управління персоналом / Ю. М. Ящишина, В. О. Шашко // Вicник економічної науки України. - 2016. - № 2 (31). С. 190-192.

3. Metodychna skarbnychka [Methodical treasury]. Retrieved from: https://www.novadoba.org.ua/sites/default/ files/files/common_history_book/methodical.pdf [in Ukrainian].

4. (2013). Farmatsevt "semy zirok" - osnova aptechnoho zakladu Yevropeiskoho zrazka [A seven-star pharmacist is the basis of a European pharmacy]. Retrieved from: http: // xn--h1adc2i.xn--j1amh/news/03518.html [in Ukrainian].

5. Yashchyshyna, Yu.M., \& Shashko, V.O. (2016). Vykorystannia interaktyvnykh metodiv navchannia pry vykladanni dystsyplin z upravlinnia personalom [Using interactive teaching methods in teaching staff management disciplines]. Visnyk ekonomichnoi nauky Ukrainy - Bulletin of Economic Science of Ukraine, 2 (31), 190-192 [in Ukrainian]. 